\title{
THE IMPACT OF AGROTECHNICAL FACTORS ON FRESH AND DRY MATTER OF OILSEED RAPE
}

\author{
Anna Sikorska' ${ }^{1}$, Marek Gugała ${ }^{2}$, Krystyna Zarzecka², Krzysztof Kapela ${ }^{3}$, Iwona Mystkowska ${ }^{4}$ \\ 1 Department of Agriculture, The State Higher School of Vocational Education in Ciechanów, Narutowicza 9, \\ 06-400 Ciechanów, Poland, e-mail: aniasikorska6@wp.pl \\ 2 Department of Agrotechnology, Faculty of Natural Sciences, Siedlce University of Natural Sciences and \\ Humanities, Prusa St. 14, 08-110 Siedlce, Poland \\ 3 Department Agrometeorology and Agricultural Eingineering, Faculty of Natural Sciences, Siedlce University \\ of Natural Sciences and Humanities, Prusa St. 14, 08-110 Siedlce, Poland \\ ${ }^{4}$ Department of Environment Sciences, Pope John Paul II State School of Higher Education, Sidorska St. 95/97, \\ 21-500 Biała Podlaska, Poland
}

Received: 2017.03.11

Accepted: 2017.04.04 Published: 2017.05.02

\begin{abstract}
The field experiment was conducted in the years of 2013-2016 at the Agricultural Experimental Station - Zawady belonging to the University of Natural Sciences and Humanities in Siedlce. The experiment was set in the split-split-plot system in three repetitions. The studied factors were: I - three varieties of oilseed rape: Monolit (population variety), PR 44D06 (hybrid restored variety with a semi dwarf growth type), PT 205 (hybrid restored variety with a traditional growth type). II - two ways of sowing: $22.5 \mathrm{~cm}$ spacing (row sowing - density of sowing 60 seeds per $1 \mathrm{~m}^{-2}$ ), 45.0 $\mathrm{cm}$ spacing (point sowing - density of sowing 40 seeds per $1 \mathrm{~m}^{-2}$ ). III - four types of bio-stimulators used: the control object (without the use of bio-stimulators), Tytanit ${ }^{\mathbb{B}}$ bio-stimulator, Asahi ${ }^{\mathbb{}} \mathrm{SL}$ bio-stimulator, Silvit ${ }^{\mathbb{}}$ bio-stimulator. The aim of the study was to determine the impact of the types of used bio-stimulators and the way of sowing on the fresh and dry mass of plants (rosette, root) of three varieties of winter oilseed rape. The fresh and dry mass of the aboveground part of rosette and the fresh and dry mass of the root system depended significantly on the genetic factor, types of used bio-stimulators and atmospheric conditions prevailing in the individual years of research. From the cultivated varieties, the largest fresh and dry mass of the aboveground part of 1 rosette (on average of $33.3 \mathrm{~g}$ and $6.34 \mathrm{~g}$ ) and the fresh and dry mass of the root system of 1 plant (an average of $7.97 \mathrm{~g}$ and $2.30 \mathrm{~g}$ ) characterised the population morphotype - Monolit. Types of the bio-stimulators used significantly impact the increased values of these characteristics. The greatest fresh and dry mass of plants (rosette, root) was noted on object 3, on which the Asahi SL bio-stimulator was used.
\end{abstract}

Keywords: varieties, bio-stimulators, winter oilseed rape, fresh and dry mass of plants, rosette, root

\section{INTRODUCTION}

The studies of many authors (Heimann 2002, Wielebski et al. 2002, Wójtowicz and Czernik - Kołodziej 2003, Wójtowicz and Jajor 2010) showed that the morphotypes of winter oilseed rape were characterised by diverse biometric features, and a different reaction to agronomic factors. According to Wójtowicz and Wielebski [2000a], Malarz et al. [2006] and Kotecki et al. [2007] genetic properties of the varieties have a strong impact on the development of rosette. Muśnicki [1989] showed the correlation between the wintering of rape and the morphology of the rosette. According to the author, the proper wintering of the rosette consisting of $8-10$ leaves 
with a low located growth cone (below $30 \mathrm{~mm}$ ), with the root neck with a thickness over $5 \mathrm{~mm}$, pile root with a length of over $15 \mathrm{~cm}$ and dry mass of the aboveground part of the plant over $1.5 \mathrm{~g}$. While Wójtowicz and Wielebski [2000b] did not find any relationships between the wintering of rape and the normal morphology of the rosette.

The aim of the study was to determine the effect of the types of used bio-stimulators and the ways of sowing on the fresh and dry mass of the aboveground part of 1 rosette and the fresh and dry mass of the root system of three varieties of winter oilseed rape.

\section{MATERIAL AND METHODS}

The field experiment was conducted in the years of 2013-2016 at the Agricultural Experimental Station - Zawady belonging to the University of Natural Sciences and Humanities in Siedlce. The experiment was set in the split-split-plot system in three repetitions. The area of one plot for harvest was $18 \mathrm{~m}^{-2}$. The studied factors were:

1. Three varieties of winter oilseed rape: Monolit (population variety), PR 44D06 (hybrid restored variety with the semi-dwarf growth type), PT 205 (hybrid restored variety with the traditional growth type).

2. Two ways of sowing $22.5 \mathrm{~cm}$ (row sowing density of sowing 60 seeds per $1 \mathrm{~m}^{-2}$ ), 45.0 spacing $\mathrm{cm}$ (point sowing - density of sowing 40 seeds per $1 \mathrm{~m}^{-2}$ ).

3. Four types of used bio-stimulators:

- control object - without using bio-stimulators,

- Tytanit ${ }^{\circledR}$ bio-stimulator: I term - in the fall in the phase of 4-8 leaves (BBCH 14-18) at a dose of $0.20 \mathrm{dm}^{3} \cdot \mathrm{ha}^{-1}$, II term - in the spring after the start of vegetation: the beginning of the development of side shoots (BBCH 21-36) at a dose of $0.20 \mathrm{dm}^{3} \cdot \mathrm{ha}^{-1}$, III term - in the phase of the development of flower buds (budding) - the beginning of April (BBCH 50-61) at a dose of 0.20 $\mathrm{dm}^{3} \cdot \mathrm{ha}^{-1}$,

- Asahi ${ }^{\circledR}$ SL bio-stimulator - in the fall in the phase of 3-5 leaves (BBCH 13-15) at a dose of $0.60 \mathrm{dm}^{3} \cdot \mathrm{ha}^{-1}$, II term - in the spring after the start of the vegetation (BBCH 28-30) at a dose of $0.60 \mathrm{dm}^{3} \cdot \mathrm{ha}^{-1}$, III term - two weeks after the performance of the second treatment at a dose of $0.60 \mathrm{dm}^{3} \cdot \mathrm{ha}^{-1}$,
- Silvit ${ }^{\circledR}$ bio-stimulator: I term -3 weeks after the emergence (BBCH 12-14) at a dose of $0.20 \mathrm{dm}^{3} \cdot \mathrm{ha}^{-1}$, II term - in the spring after the start of the vegetation $(\mathrm{BBCH}$ 28-30) at a dose of $0.20 \mathrm{dm}^{3} \cdot \mathrm{ha}^{-1}$, III term - two weeks after the performance of the second treatment at a dose of $0.20 \mathrm{dm}^{3} \cdot \mathrm{ha}^{-1}$.

The studies were conducted on the soil classified as the type of tawny soils, type - tawny, subtype - tawny, sandy soils, classified as the rye soil complex, IVa class (Marcinek and Komisarek 2011). The chemical protection against weeds, diseases and pests was used according to the recommendations of the good agricultural practice. Rape was collected in two stages, in the first and second decade of July.

Immediately before the inhibition of the autumn vegetation the following biometric characteristics were identified on the randomly selected sample of 20 plants:

- fresh mass of the aboveground part of 1 rosette $(\mathrm{g})$,

- dry mass of the aboveground part of 1 rosette (g),

- fresh mass of the root system of 1 plant (g),

- dry mass of the root system of 1 plant (g).

In the years of conducting research, there were varied weather conditions (Table 1.). In all vegetation seasons, the average annual temperature was higher than the multi-year average. The third year of the studies was the hottest, while the lowest average annual air temperature was recorded in the second year of the study. In the first and second vegetation season, the rainfall exceeded the multi-year amount, while in the last one it was smaller by $43.8 \mathrm{~mm}$. The largest annual total rainfall was recorded in the vegetation season 2014-2015, and the smallest one in the last year of studies.

\section{RESULTS AND DISCUSSION}

The study shows that the genetic factor had a significant impact on the fresh an dry mass of the aboveground part of 1 rosette and the fresh and dry mass of the root system of 1 plant (Tables 2-5). From the cultivated varieties, the largest fresh and dry mass of rosette was noted in the population form - Monolit (an average of $33.3 \mathrm{~g}$ and $6.34 \mathrm{~g}$ ), a significantly lower one was noted in the hybrid restored form with a traditional growth type - PT 205 (an average of $29.9 \mathrm{~g}$ and $5.39 \mathrm{~g}$ ), while the 
Table 1. Weather conditions in the years of experience (Zawady Meteorological Station, 2013-2016)

\begin{tabular}{|c|c|c|c|c|c|c|c|c|c|c|c|c|c|}
\hline \multirow{2}{*}{ Years } & \multicolumn{13}{|c|}{ Months } \\
\hline & VIII & IX & $x$ & $\mathrm{XI}$ & XII & 1 & II & III & IV & $\mathrm{V}$ & $\mathrm{VI}$ & VII & VIII-VII \\
\hline \multicolumn{13}{|c|}{ Rainfalls (mm) } & Sum \\
\hline 2013-2014 & 15.0 & 94.3 & 32.8 & 34.7 & 15.4 & 28.6 & 34.0 & 29.6 & 45.0 & 92.7 & 55.4 & 10.0 & 487.5 \\
\hline $2014-2015$ & 105.7 & 26.3 & 3.0 & 32.5 & 90.4 & 51.4 & 0.7 & 53.1 & 30.0 & 100.2 & 43.3 & 62.6 & 599.2 \\
\hline 2015-2016 & 11.9 & 47.1 & 37.0 & 42.2 & 16.5 & 10.9 & 29.0 & 33.5 & 28.7 & 54.8 & 36.9 & 35.2 & 383.7 \\
\hline $\begin{array}{c}\text { Multiyear sum } \\
(1996-2010)\end{array}$ & 59.9 & 42.3 & 24.2 & 20.2 & 18.6 & 19.0 & 16.0 & 18.3 & 33.6 & 58.3 & 59.6 & 57.5 & 427.5 \\
\hline \multicolumn{13}{|c|}{ Air temperature $\left({ }^{\circ} \mathrm{C}\right)$} & Mean \\
\hline $2013-2014$ & 18.8 & 11.7 & 9.3 & 5.1 & 1.2 & -4.5 & 0.7 & 5.8 & 9.8 & 13.5 & 15.4 & 20.8 & 9.0 \\
\hline 2014-2015 & 18.1 & 14.1 & 8.5 & 3.4 & 0.1 & 0.6 & 0.7 & 4.6 & 8.2 & 12.3 & 16.5 & 18.7 & 8.8 \\
\hline 2015-2016 & 21.0 & 14.5 & 6.5 & 4.7 & 3.7 & -4.5 & 2.5 & 3.5 & 9.1 & 15.1 & 18.4 & 19.1 & 9.5 \\
\hline $\begin{array}{c}\text { Multiyear mean } \\
(1996-2010)\end{array}$ & 18.5 & 13.5 & 7.9 & 4.0 & -0.1 & -3.2 & -2.3 & 2.4 & 8.0 & 13.5 & 17.0 & 19.7 & 8.2 \\
\hline
\end{tabular}

Table 2. Green matter of one plant $(\mathrm{g})$

\begin{tabular}{|c|c|c|c|c|c|c|c|c|c|c|}
\hline \multirow[b]{2}{*}{ Cultivars } & \multicolumn{4}{|c|}{ The types of bio-stimulators } & \multicolumn{2}{|c|}{ Ways of sowing } & \multicolumn{3}{|c|}{ Years } & \multirow[b]{2}{*}{ Mean } \\
\hline & $\begin{array}{c}\text { Control } \\
\text { object }\end{array}$ & Tytanit $^{\circledR}$ & Asahi ${ }^{\circledR} \mathrm{SL}$ & Silvit $^{\circledR}$ & 45.0 & 22.5 & 2013-2014 & 2014-2015 & 2015-2016 & \\
\hline Monolit & 31.6 & 33.6 & 34.9 & 33.3 & 34.5 & 32.1 & 36.4 & 37.7 & 25.8 & 33.3 \\
\hline PR 44D06 & 24.3 & 25.3 & 26.8 & 25.1 & 25.9 & 24.9 & 26.5 & 28.7 & 20.9 & 25.4 \\
\hline PT 205 & 28.2 & 30.1 & 31.0 & 30.1 & 30.5 & 29.2 & 32.2 & 33.9 & 23.4 & 29.9 \\
\hline Mean & 28.0 & 29.7 & 30.9 & 29.5 & 30.3 & 28.7 & 31.7 & 33.5 & 23.4 & - \\
\hline \multicolumn{10}{|c|}{$\begin{array}{l}\text { LSD } \\
\text { - years } \\
\text { - cultivars } \\
\text { - ways of sowing } \\
\text { - the types of bio-stimulators } \\
\text { Interaction: } \\
\text { - years } x \text { cultivars } \\
\text { - cultivars } x \text { ways of sowing } \\
\text { - cultivars } x \text { the types of bio-stimu }\end{array}$} & $\begin{array}{l}0.3 \\
0.3 \\
\text { n.s. } \\
0.3 \\
\\
\text { n.s. } \\
\text { n.s. } \\
\text { n.s. }\end{array}$ \\
\hline
\end{tabular}

Table 3. Dry matter of one plant $(\mathrm{g})$

\begin{tabular}{|c|c|c|c|c|c|c|c|c|c|c|}
\hline \multirow[b]{2}{*}{ Cultivars } & \multicolumn{4}{|c|}{ The types of bio-stimulators } & \multicolumn{2}{|c|}{ Ways of sowing } & \multicolumn{3}{|c|}{ Years } & \multirow[b]{2}{*}{ Mean } \\
\hline & $\begin{array}{c}\text { Control } \\
\text { object }\end{array}$ & Tytanit $^{\circledR}$ & Asahi ${ }^{\circledR} \mathrm{SL}$ & Silvit $^{\circledR}$ & 45.0 & 22.5 & 2013-2014 & 2014-2015 & 2015-2016 & \\
\hline Monolit & 6.01 & 6.39 & 6.62 & 6.36 & 6.56 & 6.13 & 6.90 & 6.90 & 5.23 & 6.34 \\
\hline PR 44D06 & 4.21 & 4.38 & 4.64 & 4.36 & 4.48 & 4.31 & 4.23 & 4.70 & 4.25 & 4.39 \\
\hline PT 205 & 5.11 & 5.44 & 5.60 & 5.43 & 5.52 & 5.27 & 5.62 & 5.80 & 4.77 & 5.39 \\
\hline Mean & 5.11 & 5.40 & 5.62 & 5.38 & 5.52 & 5.24 & 5.58 & 5.80 & 4.75 & - \\
\hline \multicolumn{10}{|c|}{$\begin{array}{l}\mathrm{LSD}_{0.05} \text { for: } \\
\text { - years } \\
\text { - cultivars } \\
\text { - ways of sowing } \\
\text { - the types of bio-stimulators } \\
\text { Interaction: } \\
\text { - years } x \text { cultivars } \\
\text { - cultivars } x \text { ways of sowing } \\
\text { - cultivars } x \text { the types of bio-stims }\end{array}$} & $\begin{array}{c}0.05 \\
0.05 \\
\text { n.s. } \\
0.06 \\
0.10 \\
\text { n.s. } \\
\text { n.s. }\end{array}$ \\
\hline
\end{tabular}

smallest one in the hybrid restored form with the semi-dwarf growth type - PR 44 D06 (an average of $25.4 \mathrm{~g}$ and $4.39 \mathrm{~g}$ ). Similar conclusions were reached by Kotecki et al. [2007]. The authors have also obtained higher values of the discussed features in the population morphotype Lisek. On the other hand, according to Wielebski and Wójtowicz [2001], Malarz et al. [2006] and Jankowski and Budzyński [2007] and Wielebski [2007] the heterosis forms have created the rosette with a higher fresh and dry mass of 1 plant. Own studies have shown that the highest fresh and dry mass 
of the root system was obtained in the population variety Monolit - an average of $7.97 \mathrm{~g}$ and $2.30 \mathrm{~g}$, a significantly lower in the hybrid restored form with a traditional growth type PT 205 - an average of $7.13 \mathrm{~g}$ and $2.03 \mathrm{~g}$, while the smallest one in the semi-dwarf variety PR 44D06 - an average of $6.04 \mathrm{~g}$ and $1.73 \mathrm{~g}$ (Table 4 and 5). While Wielebski [2007] stated the largest mass of roots in the hybrid complex and restored varieties.

The conducted studies and statistical calculations did not confirm the significant impact of the ways of sowing on the fresh and dry mass of plants (rosette, root) (Tables 2-5). However, a higher fresh mass of the aboveground part of 1 rosette was obtained in a wide spacing between rows $(45.0 \mathrm{~cm})$ and it was on average $30.3 \mathrm{~g}$., while in a $22.5 \mathrm{~cm}$ spacing, the average of 28.7 $\mathrm{g}$ was obtained. A similar trend was observed in the case of the dry matter of the aboveground part of 1 rosette. Muśnicki and Budzyński [2005] obtained plants with a greater aboveground mass using the row spacing of $12.0-15.0 \mathrm{~cm}$ compared to the crop with the spacing of $30.0-40.0 \mathrm{~cm}$. Similarly, Kotecki et al. [2007] in a wider spacing of rows obtained a smaller content of dry and fresh mass of 1 plant, an average of $6.0 \%$ and $5.0 \%$.

The analysis of variance showed a significant impact of the used bio-stimulators on the dry and fresh mass of the aboveground part of rosette (Table 2 and 3). The greatest value of the discussed feature was obtained on the objects, on which the Asahi SL bio-stimulator was used - an average of $30.9 \mathrm{~g}$ and $5.62 \mathrm{~g}$, a significantly lower under the influence of the other bio-stimulators (Tytanit and Silvit). These results were confirmed in the studies by Gawrońska et al. [2008], who as a result of the use of the Asahi SL bio-stimulator have also obtained the increased accumulation of biomass (fresh and dry). In own studies, the highest fresh and dry mass of the root system of 1 plant was noted on object 3, on which the Asahi SL was used, and the smallest one on the control plots (Table 4 and 5).

Statistical calculations showed a significant impact of the climatic conditions in the years of the studies on the fresh and dry mass of the aboveground part of 1 rosette (Tables 2-5). The greatest values of the discussed features - an average of $33.5 \mathrm{~g}$ and $5.80 \mathrm{~g}$ were stated in the second year of studies marked by the heavy rainfall in August and alternating rainfall in September and a higher air temperature than the multi-year average in September and October, while the small- est one - an average of $23.4 \mathrm{~g}$ and $4.75 \mathrm{~g}$ was achieved in the vegetation season of 2015-2016, with a strong drought in August and in the two first decades of September. A similar trend was observed in the case of the fresh and dry mass of the root system of 1 plant (Tables 4-5).

Statistical calculations did not show any significant interactions of the years and the studied varieties on the value of fresh mass of the aboveground 1 rosette, what means that the varieties showed a similar reactions to the humidity and thermal conditions in the research years (Table 2). Different results were achieved by Kotecki et al. [2007], who demonstrated the interaction of the studied factors. Own studies stated the interactions of years and the studied varieties on the value of dry mass of the aboveground part of 1 rosette, which shows the different reaction of varieties to the changing climatic conditions in different growing seasons (Table 3). The Monolit variety was characterised by the same dry mass of the aboveground mass of 1 rosette in the first and second growing season and it was significantly higher than in the last year of studies. A similar trend was observed in a semi-dwarf hybrid in the first and second vegetation season. The heterosis variety PT 205 was characterised by a significant diversity of the feature value in the research years. In this variation, the highest dry mass of the aboveground part of 1 rosette was obtained in the second years of studies, a significantly smaller in 2013-2014, while the smallest in 2015.

A significant correlation was shown between the years with varieties on the fresh and dry mass of the root system, which proves a different reaction of rape varieties on the changing weather conditions in the research years (Tables 4 and 5).

\section{CONCLUSIONS}

1. The morphotype has a significant impact on the fresh and dry mass of the aboveground part of 1 rosette and the fresh and dry mass of the root system of 1 plant. The population variety Monolit, compared to the restored hybrids PT 205 and PR 44D06, had higher values of the discussed features.

2. Bio-stimulators used in the experiment affected the increase of the fresh and dry mass of plants. Under the influence of the Asahi SL bio-regulator, the highest values of the fresh and dry mass of plants were achieved (rosette, root). 
Table 4. Green matter of the root system of one plant (g)

\begin{tabular}{|c|c|c|c|c|c|c|c|c|c|c|}
\hline \multirow{2}{*}{ Cultivars } & \multicolumn{4}{|c|}{ The types of bio-stimulators } & \multicolumn{2}{|c|}{$\begin{array}{l}\text { Ways of } \\
\text { sowing }\end{array}$} & \multicolumn{3}{|c|}{ Years } & \multirow{2}{*}{ Mean } \\
\hline & $\begin{array}{l}\text { Control } \\
\text { object }\end{array}$ & Tytanit $^{\circledast}$ & Asahi®SL & Silvit ${ }^{\circledR}$ & 45.0 & 22.5 & 2013-2014 & 2014-2015 & 2015-2016 & \\
\hline Monolit & 7.56 & 8.02 & 8.32 & 7.97 & 8.26 & 7.68 & 9.13 & 9.10 & 5.68 & 7.97 \\
\hline PR 44D06 & 5.81 & 6.03 & 6.34 & 5.98 & 6.14 & 5.94 & 6.64 & 6.89 & 4.60 & 6.04 \\
\hline PT 205 & 6.74 & 7.18 & 7.40 & 7.19 & 7.29 & 6.97 & 8.07 & 8.17 & 5.16 & 7.13 \\
\hline Mean & 6.70 & 7.08 & 7.36 & 7.05 & 7.23 & 6.86 & 7.94 & 8.05 & 5.15 & - \\
\hline \multicolumn{10}{|c|}{$\begin{array}{l}\mathrm{LSD}_{0.05} \text { for: } \\
\text { - years } \\
\text { - cultivars } \\
\text { - ways of sowing } \\
\text { - the types of bio-stimulators } \\
\text { Interaction: } \\
\text { - years } x \text { cultivars } \\
\text { - cultivars } x \text { ways of sowing } \\
\text { - cultivars } x \text { the types of bio-stim }\end{array}$} & $\begin{array}{c}0.07 \\
0.07 \\
\text { n.s. } \\
0.10 \\
\\
0.13 \\
\text { n.s. } \\
\text { n.s. } \\
\end{array}$ \\
\hline
\end{tabular}

Table 5. Dry matter of the root system of one plant (g)

\begin{tabular}{|c|c|c|c|c|c|c|c|c|c|c|}
\hline \multirow{2}{*}{ Cultivars } & \multicolumn{4}{|c|}{ The types of bio-stimulators } & \multicolumn{2}{|c|}{$\begin{array}{l}\text { Ways of } \\
\text { sowing }\end{array}$} & \multicolumn{3}{|c|}{ Years } & \multirow{2}{*}{ Mean } \\
\hline & $\begin{array}{l}\text { Control } \\
\text { object }\end{array}$ & Tytanit ${ }^{\circledR}$ & Asahi®SL & Silvit ${ }^{\circledR}$ & 45.0 & 22.5 & 2013-2014 & 2014-2015 & 2015-2016 & \\
\hline Monolit & 2.18 & 2.32 & 2.42 & 2.31 & 2.39 & 2.22 & 2.66 & 2.54 & 1.72 & 2.30 \\
\hline PR 44D06 & 1.67 & 1.72 & 1.81 & 1.71 & 1.76 & 1.69 & 1.84 & 1.94 & 1.40 & 1.73 \\
\hline PT 205 & 1.93 & 2.04 & 2.11 & 2.04 & 2.08 & 1.99 & 2.28 & 2.27 & 1.54 & 2.03 \\
\hline Mean & 1.92 & 2.03 & 2.11 & 2.02 & 2.07 & 1.97 & 2.26 & 2.25 & 1.55 & - \\
\hline \multicolumn{10}{|c|}{$\begin{array}{l}\mathrm{LSD}_{0.05} \text { for: } \\
\text { - years } \\
\text { - cultivars } \\
\text { - ways of sowing } \\
\text { - the types of bio-stimulators } \\
\text { Interaction: } \\
\text { - years } x \text { cultivars } \\
\text { - cultivars } x \text { ways of sowing } \\
\text { - cultivars } x \text { the types of bio-stimul }\end{array}$} & $\begin{array}{c}0.03 \\
0.03 \\
\text { n.s. } \\
0.03 \\
\\
0.04 \\
\text { n.s. } \\
\text { n.s. }\end{array}$ \\
\hline
\end{tabular}

3. The varied course of weather in the years of the experiment affected the values of the discussed characteristics. The highest values of the fresh and dry mass of the aboveground part of 1 rosette and the fresh and dry mass of the root system of 1 plant were stated in the second year of studies marked by heavy rainfall in August and the alternating rainfall in September and a higher air temperature than the multi-year average in September and October.

4. Increasing the spacing of the rows from 22.5 $\mathrm{cm}$ to $45.0 \mathrm{~cm}$ did not significantly affect the values of these characteristics.

\section{REFERENCES}

1. Gawrońska H., Przybysz A., Szalacha E., Słowiński A. 2008. Physiological and molecular mode of ac- tion of Asahi SL biostimulator under optimal and stress conditions. In: ed. H. Gawronska. Biostimulators in modern agriculture, General Aspects, Wieś Jutra, 54-76, Warsaw, Poland

2. Heimann S. 2002. Aktualne problemy dotyczące badania odmian rzepaku na cele konsumpcyjne oraz biopaliwo i makuchy. Forum producentów roślin zbożowych, kukurydzy i rzepaku. Polagra - Forum, 47-52

3. Jankowski K.J., Budzyński W. 2007. Reakcja różnych form hodowlanych rzepaku ozimego na termin i gęstość siewu I. Jesienny wzrost i rozwój oraz przezimowanie roślin. Rośliny Oleiste - Oilseed Crops, XXVIII (2), 177-194.

4. Kotecki A., Malarz W., Kozak M., Pogorzelec A. 2007. Wpływ rozmieszczenia roślin w łanie na rozwój i plonowanie mieszańcowych i populacyjnych odmian rzepaku. Część I. Morfologia roślin i plony nasion. Zesz. Nauk. Uniwersytetu Przyrodniczego we Wrocławiu, Rolnictwo XC (553), 7-39. 
5. Malarz W., Kozak M., Kotecki A. 2006. Wpływ zagęszczenia roślin w łanie na wysokość i jakość plonu trzech odmian rzepaku ozimego. Rośliny Oleiste - Oilseed Crops, XXVII (1), 299-310.

6. Marcinek J., Komisarek J. 2011. Roczniki gleboznawcze, Wydawnictwo "Wieś Jutra", Warszawa, LXII, 3, 1-190.

7. Muśnicki Cz. 1989. Charakterystyka botaniczno - rolnicza rzepaku ozimego i jego plonowanie w zmiennych warunkach środowiskowo - agrotechnicznych. Rocz. Akademii Rolniczej w Poznaniu. Seria Rozprawy Naukowe, 191, 93-112.

8. Muśnicki Cz., Budzyński M. 2005. Uprawa roli i siew rzepaku. Rozdział w: Technologia produkcji rzepaku. Wydawnictwo Wieś Jutra, Warszawa: 90-96.

9. Wielebski F., Wójtowicz M. 2001. Wpływ gęstości siewu na plon nasion oraz cechy morfologiczne i elementy struktury plonu odmian populacyjnych i mieszańcowych rzepaku ozimego. Rośliny Oleiste - Oilseed Crops, XXII (2), 349-362.

10. Wielebski F., Wójtowicz M., Horodyski A. 2002. Agrotechnika rzepaku ozimego w badaniach
Zakładu Roślin Oleistych IHAR w Poznaniu. Rośliny Oleiste - Oilseed Crops, XXIII (1): 31-52.

11. Wielebski F. 2007. Reakcja różnych typów odmian rzepaku ozimego na zmienne zagęszczenie roślin w łanie I. Plon nasion i jego składowe. Rośliny Oleiste - Oilseed Crops, XXVIII (2), 209-226.

12. Wójtowicz M., Wielebski F. 2000a. Porównanie zrestorowanych odmian mieszańcowych z odmianą wyprowadzoną z linii podwojonych haploidów i odmianami populacyjnymi rzepaku ozimego. Rośliny Oleiste - Oilseed Crops, XXI (1), 55-64.

13. Wójtowicz M., Wielebski F. 2000b. Wpływ warunków siedliskowych na jesienny rozwój oraz przezimowanie dwóch odmian rzepaku ozimego. Rośliny Oleiste-Oilseed Crops, XVIII(1), 179-186.

14. Wójtowicz M., Czernik-Kołodziej K. 2003. Reakcja zarejestrowanych odmian rzepaku ozimego na poziom agrotechniki. Rośliny Oleiste - Oilseed Crops, XXIV (1), 85-94.

15. Wójtowicz M., Jajor E. 2010. Wpływ wybranych czynników technologii produkcji na plony rzepaku ozimego. Prog. Plant Prot./Post. Ochr. Roślin 50(2), 565-569 